\title{
The corporate branding in international operations
}

\author{
$J_{\text {Juliana Rodrigues }}{ }^{\mathrm{A}}$, Bruno Mazzola ${ }^{\mathrm{A}}$, Mariana Bassi Sutter ${ }^{\mathrm{B}}$, \\ Ney Nakazato Miyahira ${ }^{\mathrm{A}}$ e Maria Tereza Leme Fleury ${ }^{\mathrm{C}}$

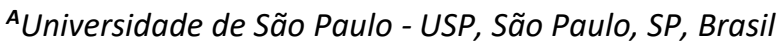 \\ ${ }^{B}$ The University of York, York, England, United Kingdom \\ ${ }^{C}$ Fundação Getúlio Vargas, FGV EAESP, São Paulo, SP, Brasil
}

\section{ARTICLE DETAILS}

\section{Article history:}

Received 5 March 2016

Accepted 14 March 2017

Available online in 30 April 2017

Double Blind Review System

\section{Scientific Editor}

Ilan Avrichir

\section{Keywords:}

Corporate brand

Corporate branding

International marketing

Brand architecture

International business

\begin{abstract}
Corporate branding is increasingly gaining relevance in companies' internationalization; however, few studies directly address the influence and use of corporate branding in processes of internationalization. This study examines these topics and shows the corporate brand as a critical capability in relationships with different stakeholders. A literature review explores corporate branding approaches in international business. In addition, a quantitative exploratory study was conducted using a survey with 297 management-level professionals in Brazil in order to find out if company operation scopes, whether local or multinational, interfere with views on corporate branding. The findings highlight the construction of identity in multinationals as one of the main reasons for adopting corporate brands. However, company operation scopes do not significantly interfere with the hierarchy of reasons perceived as important in the adoption of corporate branding. An emphasis on the concept of corporate branding based on organizational identity was noted among respondents who work at multinationals, showing the relevance of this topic for future research.
\end{abstract}

(C) 2017 Internext | ESPM. All rights reserved.

\section{Introduction}

Globalization has set a new conception of interaction and global flows in various sectors of society and the economy. The extending firm activities outside the country-of-origin borders are often presented as an important step in the search for firm expansion. Firm internationalization allows access to new markets, generating significant benefits such as increased product lifecycle management and operational revenues, more lucrative profits, and market diversification, with the consequent dilution of risks (Kovacs, Moraes, \& Oliveira, 2007). However, as globalization allows easier access to new international markets, it also creates a fierce competitive environment, which requires continuous increases in business competitiveness. Thus, inclusion in this new business space demands

${ }^{1}$ Author's contact: jurodrigues@usp.br elaborate and careful planning, which is part of broader strategic organization.

Although there are several theories about the process of firm internationalization, exporting is, in most cases-and especially in the models of a behavioral bias - seen as one of the first steps in the gradual process of penetration. It is often used to gain experience and knowledge in the internationalization process, giving the firm a richer export culture (Ferreira, Cavalcanti Neto, \& Gomes, 2014). Despite appearing as the simplest mode of entry, one that does not need great firm control, exporting should be a strategically planned action and can require major changes in organization.

For firms that aim to export their products, a major challenge is the choice of market. One of the most critical dilemmas in the analysis of a new international market is the choice between a higher 
level of detail and the resulting quality of the analysis verses the costs and time involved in decision making. It is especially important for small- and medium-sized firms that have limited resources for this task and subsequent international market entry. Currently, there is also a growing need to make quicker decisions, due to the pace with which international trade and scenarios change (Teixeira \& Flores, 2014).

It is essential that the prospecting process for new international markets is supported by strong and effective study, which can assist decision-makers to make the most appropriate choice in a limited period of time. The use of competitive intelligence $(\mathrm{Cl})$ is therefore a key strategic process to reduce uncertainty and to better understanding economic, political, legal and cultural forces in international markets. According to Fuld (2007), Cl allows anticipated forward action to understand, in a lessthan-perfect way, external contexts. $\mathrm{Cl}$ allows information from the external environment to be analyzed and forms of activity in this market to be understood, so that the firm can define the best establishment strategy (Woida \& Valentim, 2006).

$\mathrm{Cl}$ can be used to select export markets. The use of $\mathrm{Cl}$ supports firm decision-makers in various aims (Barreto, 2012). Its use in the selection of export markets is an opportunity, helping to reduce the risk of an important step in the internationalization process of a firm. Thus, this study seeks to investigate how $\mathrm{Cl}$ can assist the process of selecting new markets in exporting activities.

This research has the main objective of analyzing the way in which $\mathrm{Cl}$ aids the selection of new markets. As specific objectives, similarities between $\mathrm{Cl}$ models related to market selection for exporting and method differences are identified in order to reveal their contribution capacity.

\section{Theoretical foundation}

\subsection{The corporate brand concept}

The corporate brand encompasses a wide range of corporate entities - companies, corporations, subsidiaries, business groups, and brand associations (Balmer \& Gray, 2003). At the corporate level, it gives a special meaning to the institutional level of organizations, expanding the points of contact and relationships with multiple stakeholders through the use of a greater variety of tangible and intangible elements (Aaker, 2004; Balmer \& Gray, 2003; Kay, 2006; Knox \& Bickerton, 2003; Pérez \& del Bosque, 2014). Unlike product brands, which usually deal with a specific group of stakeholders - mostly customers who buy and use the product - corporate brands extend contact to a larger group of internal and external stakeholders through a cumulative and longterm process of building trust on different topics at an organizational level (Balmer \& Gray, 2003; Xie \& Boggs, 2006).

It involves an interdisciplinary field of knowledge and practices, including business, administration, marketing, architecture, design/arts, and communication (Balmer \& Gray, 2003; Fetscherin \& Usunier, 2012; King, 1991). It is worth noting that the corporate brand concept is relatively recent - more expressive in the 1990s - and an interdisciplinary field, which involves different schools and approaches (Balmer \& Gray, 2003; Fetscherin \& Usunier, 2012; King, 1991). In a study on corporate brand literature, Fetscherin and Usunier (2012) found three main approaches: transactional, internal, and external. The transactional approach is about corporate branding and what companies do (product, service, sponsorship). The second approach is internal to the company, with research directed to the corporate brand and what companies are (corporate and/or visual identity), besides considering the profile of people it attracts (image as an employer and adoption). The third approach, related to corporate reputation, is external and focuses on the influence of bad corporate behavior (crime and crisis), the influence of corporate image on performance (financial performance) and customer loyalty, and how the company is perceived in public opinion and society.

Such variability of corporate brand approaches is a consequence of different theoretical perspectives, from different areas, that address this subject. Balmer and Gray (2003) summarized these different schools according to the specific focus of their definition and area of influence, seen as: (1) marks/design - denoting ownership (such as coats of arms, from the "sender-end" perspective); (2) image and construction of reputation devices (process of "persuasion" also linked to the consumer); (3) symbols associated with key values and culture (values associated with the organization and its products and services - brands used as quality assurance or security against risks); (4) means for building individual identities and differentiation (the 
brand as an identity attribute from a consumer perspective); (5) pleasant experience consumption channels.
Considering the categorization of the theoretical fronts proposed, a possible grouping of five main definitions and approaches - differentiated by their specific focus - related to corporate branding was identified, as shown in Table 1.

Tab. 1

Corporate brand definition approaches

\begin{tabular}{ll}
\hline Corporate brand definitions & $\begin{array}{l}\text { Approaches } \\
\text { based on (Balmer \& Gray, 2003) }\end{array}$ \\
\hline $\begin{array}{l}\text { Corporate brand management is related to the design of the symbol or the organization's } \\
\text { visual representation of a product or service as well as the visual identity of all } \\
\text { communications and interactions promoted by the company. }\end{array}$ & Signals/Design \\
\hline $\begin{array}{l}\text { Corporate brand management is the process of building a positive company image and } \\
\text { persuasion before consumers and other stakeholders. }\end{array}$ & Image/Reputation \\
\hline $\begin{array}{l}\text { Corporate brand management is the representation of symbols associated with the } \\
\text { company's key values and culture as well as its products and services. }\end{array}$ & Key values/Culture \\
\hline $\begin{array}{l}\text { Corporate brand management is a means of differentiation among competitors and the } \\
\text { construction of individual and collective identity. }\end{array}$ & Differentiation/ldentity \\
\hline $\begin{array}{l}\text { Corporate brand management is the construction of a corporate narrative and is a driver of } \\
\text { positive experiences with the organization. }\end{array}$ & Experiences/Narrative \\
\hline
\end{tabular}

Source: Rodrigues, Miyahira, Mariano, \& Marine (2014)

\subsection{Reasons for corporate brand adoption}

From an interdisciplinary and comprehensive view of corporate branding and relationships with multiple stakeholders, different motives are addressed to explore the reasons and benefits of its adoption as part of strategy. Einwiller and Will (2002) carried out one of the first studies on the reasons perceived as relevant in investing in corporate branding, which involved qualitative research with executives of European multinationals. The researchers defined five main groups: (1) coordination and management of identity problems in multinational operations building a common positioning of values and ideas as an umbrella in integration and management; (2) increasing importance of the capital market and the influence of a favorable reputation as a prerequisite in the relationship with investors and stock trading; (3) war for talent in attracting and retaining the best professionals as well as employees' general satisfaction and evaluation as a great place to work; (4) need to create synergy between brands increased customer criticality and the possibility of extending brands; (5) increasing demand for transparency, due to increasing legal obligations, combined with cumulative pressure for transparency and interest in information.

In the corporate branding literature, authors address a wide range of reasons and benefits of investing in corporate brands. After a revision (Rodrigues et al., 2014), as Table 2 shows, 26 reasons were listed and grouped into 12 main categories: war for talent (employer branding); synergy between brands; consumer attraction; commercial relations; multinationals and holdings; strategic repositioning; demand for transparency; single face with stakeholders; social responsibility and sustainability; capital market; organizational identity; image and reputation. Possible reasons are understood as expected results, perceived benefits, and market assumptions, which may be considered as relevant reasons to adopt this strategy. These reasons, grouped into categories, gave rise to the research variables used in the preparation of the questionnaire. 
Tab. 2

Reasons to adopt corporate branding

\begin{tabular}{|c|}
\hline Lis of reasons \\
\hline 1. War for Talent (Employer Branding) \\
\hline 1.2. Competition for the best professionals \\
\hline 1.3. Retaining talents \\
\hline 2. Synergy between brands (product and corporate) \\
\hline 2.1. Corporate brand can strengthen product brands \\
\hline 2.2. Synergy between different business units and product brands \\
\hline 2.3. Investment focuses on promotion and communication \\
\hline 3. Attracting consumers (B2C-business to consumer) \\
\hline 3.2. Identification of the origin of the product \\
\hline 3.3. Win consumer preference and loyalty \\
\hline 4. Commercial relations (B2B - business to business) \\
\hline 4.1. Positioning and customer attraction in B2B companies \\
\hline 4.2. Increased leverage in negotiating with dealers and suppliers \\
\hline 5. Multinational operations and holdings \\
\hline 5.1. Common identity and positioning in different countries \\
\hline $\begin{array}{l}\text { 5.2. Integration of positioning and change management through mergers and } \\
\text { acquisitions }\end{array}$ \\
\hline 6. Strategic repositioning and change management* \\
\hline 6.1. Mergers and acquisitions \\
\hline 6.2. Internal engagement for change \\
\hline 6.3. Commercial and external repositioning \\
\hline 7. Demand for transparency \\
\hline 7.1. Legal obligations of corporate governance and disclosing of financial reporting \\
\hline $\begin{array}{l}\text { 7.2. Pressure for transparency by financial markets, media, internet, and the general } \\
\text { public. }\end{array}$ \\
\hline 8. Single face of relationship stakeholders \\
\hline
\end{tabular}

8.1. Integration of discourse and unique positioning

(Aaker, 2004; Balmer \& Gray, 2003; Einwiller

\& Will, 2002; Kay, 2006; King, 1991)

(Aaker, 2004; Balmer \& Gray, 2003; Corte \& Mangia, 2011; Einwiller \& Will, 2002; Harris \& Chernatony, 2001; Hatch \& Schultz, 2003, 2008)

(Aaker, 2004; Einwiller \& Will, 2002; Hatch \& Schultz, 2003; Kay, 2006; van Riel \& Balmer, 1997; van Riel \& Fombrun, 2007)

(Glynn, Motion, \& Brodie, 2007; Keller \& Machado, 2006; King, 1991; Leek \& Christodoulides, 2011; Sheikh \& Lim, 2011)

(Balmer \& Gray, 2003; Einwiller \& Will, 2002; Olins, 1989; van Riel \& Fombrun, 2007)

(Argenti, 2005; Cheney, Christensen, Zorn, \& Ganesh, 2004; Einwiller \& Will, 2002; Kay, 2006; van Riel \& Fombrun, 2007)

(Argenti, 2005; Harris \& Chernatony, 2001; Hatch \& Schultz, 2003, 2009; van Riel \& Fombrun, 2007)

(Aaker, 2004; Balmer \& Gray, 2003; Einwiller \& Will, 2002; Hatch \& Schultz, 2008; van Riel \& Fombrun, 2007)

\section{Social Responsibility and Sustainability}

9.1. Demand for social and environmental responsibility

(Aaker, 2004; Balmer \& Gray, 2003; Einwiller \& Will, 2002; Hatch \& Schultz, 2008)

9.2. Relationship with the community

\section{Increase value in capital markets}

10.1. Prerequisite of strong corporate brand and favorable reputation

(Einwiller \& Will, 2002; Kotler \& Pfoertsch, 10.2. Influence on share value 2007)

10.3. Reputation as a deciding factor in purchasing shares

\section{Organizational identity \\ 11.1. Brand's ability to communicate values and culture \\ 11.2. Employees' sense of belonging and identity building}

\section{Image and Reputation}

12.1. Crisis prevention

12.2. Brand value as intangible asset (Brand Equity)

Source: adapted from Rodrigues et al. (2014)

1.3 The role of corporate branding in international business
The international marketing literature has as one of its central research themes the decision about how to enter a new market and mode of operation (Cavusgil et al., 2010; Cavusgil, Deligonul, \& Yaprak, 2005; Ghauri et al., 2011; Katobe, 2001; Zou \& 
Cavusgil, 2002). There are several factors that influence how multinationals entry and operate in a new market, such as the international environment (economic, cultural, and legal) as well as company strategy (Katobe, 2001). Fleury and Fleury (2012) emphasize the importance of analyzing the process of internationalization based on: (1) the company as the unit of analysis - contemplating its strategy, leadership style, competencies, and performance indicators; and (2) the context in which it operates that is, (a) the local environment - infrastructure, socio-politics, local culture, the local endowment of factors, nature, people, and capital; (b) the competitive environment - markets, products, corporations, institutions, and NGOs; and (c) the global environment.

Ghauri et al. (2011) emphasize that a marketoriented approach builds sustainable competitive advantage by providing unique and superior benefits to consumers. The way a company brings about these benefits depends on its internal critical capability. These include learning, configuration, networking, and brand capabilities, especially the corporate brand and internal alignment with the workforce.

Branding is one of the first components of marketing strategy to be internationally addressed (Chabowski et al., 2013). It stands out as a very important topic for companies operating in international markets (Chabowski et al., 2013; Xie \& Boggs, 2006), becoming a valuable asset to the growth of globalized business (Lim \& O'Cass, 2001). Chabowski et al., (2013) argue that global branding relates to the planned choice of methods and strategies, which may represent the process of independent brand selection and management in various markets, involve a rigorous focus on the development and use of internationally homogeneous brands, or even a combination of both concepts.

In increasingly complex organizations, brand management is, therefore, beyond the planning of each name and/or category of products and services. Brand architecture - that is, how organizations structure brands and how these brands interrelate should shape company strategy and help to convey the unique differentiating elements of organizations (Hatch \& Schultz, 2008; Olins, 1989; van Riel \& Fombrun, 2007). The architecture includes the choice of approach and positioning at different levels corporate, business, products, services; brand extension through product lines or to countries; and to what extend the branding is compatible and coordinated through national borders (Douglas \& Craig, 2013). Emphasis on corporate brands of businesses or products varies according to the company, considering internal and external factors such as the role of corporate image in strategy, the variety of business units, and relationships with customers and stakeholders (Douglas \& Craig, 2013; Muzellec \& Lambkin, 2009; Xie \& Boggs, 2006). Despite the emphasis of the international marketing literature on product brands (Ghauri et al., 2011; Xie $\&$ Boggs, 2006), it is not about product brands versus corporate brand but a structured choice through the definition of global brand architecture (Douglas \& Craig, 2013; Douglas et al., 2001; Muzellec \& Lambkin, 2009).

However, studies directly focused on the role of the corporate brand in strategy and the process of internationalization are scarce. Ghauri et al. (2011) also found greater emphasis on product brands and emerging markets in international marketing publications, even though corporate brands are fundamentally important for the relationship with more diverse stakeholders such as employees (Ghauri et al., 2011). This is because relationships are a reputation management tool and channel the projection of identity, values, and strategy in a planned and structured way (Balmer, 2009, 2012; Balmer \& Gray, 2003; Balmer \& Greyser, 2006; Hatch \& Schultz, 2003, 2008; Kay, 2006; Urde, 2009, 2013; van Riel \& Fombrun, 2007).

Research conducted by the authors in October 2014 and revised in February 2016 resulted in few studies that combined the topics "international business"/"international marketing" and "corporate branding". The research focused on various terms related to these topics such as: "corporate branding," "corporate brand," "corporate identity," "international business," "international marketing," "multinationals," and "global corporate branding," among others. International data sources were consulted using the portal ISI Web of Knowledge as well as specific searches in reference journals on international business. These included the Journal of International Business, International Journal of Management, Journal of World Business, International Business Review, Management International Review, and Academy of Management Journal. National Brazilian data sources were also consulted through the SPELL database. Despite 
recent bibliometric articles in both fields - corporate branding (Fetscherin \& Usunier, 2012) and global branding (Chabowski et al., 2013) - which have relevant indirect correlations between the topics, they do not clearly show the influence of corporate branding in international marketing strategy and vice versa.

According to Ghauri et al. (2011), in a marketoriented approach, the focus is on the sphere of business processes and the general strategic role of companies in external environments, and, therefore, a special focus on corporate brand, rather than individual product brands, becomes more conceivable. Xie and Boggs (2006) corroborate this statement in a study on internationalization in emerging markets, proposing a conceptual framework for thinking about the most suitable brand emphasis - that is, product versus corporate branding. Through eight propositions, conditionings that stimulate or suppress the adoption of corporate brand were identified: interests of multiple stakeholders; emphasis on corporate image by stakeholders in emerging markets; complexity of the market; marketing costs; differences between industrial and consumer products; company size; period of experience; and extension of international experience. Perception of the country of origin is also included (Đorđević, 2008; Guzmán \& Paswan, 2009; Lim \& O'Cass, 2001; Pharr, 2005). Pérez and del Bosque (2014) corroborate Ghauri et al. (2011) and Xie and Boggs's (2006) arguments by stating that, compared to the attributes of services and products, organizational attributes of corporate brands are more durable and resistant to competitive pressures.

Ghauri et al. (2011) also indicate the importance of corporate brand to attract, align, and engage employees in international operations as critical audiences for the success of business strategy. "Market-driving firms have a stronger branding capability, which is based mainly on the corporate brand as a force to create a strong external image and to align local employees with key company values." (Ghauri et al., 2011, p. 11). In this sense, the view of corporate brands in international business shows itself as more adherent to the approach as a representation of symbols associated with key company values, culture, as well as its products and services. This happens in a process of building and strengthening the projection of organizational identity, reinforcing its strategic character as a planned choice of elements in order to unify its message and positioning (Hatch \& Schultz, 2008; Urde, 2003, 2009; van Riel \& Fombrun, 2007).

Therefore, the question appears of if the place where the organization operates (national or international) interferes with views on the relevance of those reasons. The corporate brand plays an important role in the complexity of international operations and relationship with different stakeholders, which mainly expresses corporate positioning. In order to discuss corporate branding in international branding strategy, this study seeks to explore corporate brand approaches through the context of executives of organizations operating in Brazil.

\section{Method}

This exploratory and descriptive study (Vergara, 2009) seeks to understand the association still little explored in the literature between two topics: corporate branding and internationalization. The reflection promoted by the literature review highlights corporate branding as a critical capability in international business. Thus, quantitative field research was conducted, "whose purpose is the delineation or analysis of the characteristics of facts or phenomena" (Lakatos \& Marconi, 2003, p. 86).

The empirical study's central question relates to whether the fact that the company has local or multinational operations interferes with views on corporate branding. Since identity in multinational is one of the main reasons to adopt corporate branding (Einwiller \& Will, 2002), the hierarchy of reasons for adoption was established in accordance with the organizations' operational contexts.

The questionnaire was elaborated by the authors as part of a comprehensive study on corporate branding. They mapped 26 reasons, grouped into 12 central categories, which gave rise to the research variables, considering the relevant reasons to adopt corporate brands. They were converted into affirmative questions, randomly ordered in the questionnaire, and used a 5-point Likert scale. Two affirmative questions contrary to the brand were included to control the quality of completion of the questionnaire. The questionnaire also included multiple-choice questions about the most suitable definition/approach of the corporate brand in the respondents' view as well as questions on sample qualification, including the place where the company operates (national, national with international 
operations, or multinational with operations in Brazil). These made up the sample adopted for analysis in this study.

The research sphere deals with professionals who occupy high hierarchical positons, allowing them to have a broader company perspective - that is, those who belong to management positions in Brazilian organizations or multinationals operating in Brazil. Considering that it is a survey, primary data collection method was carried out through questionnaires to be completed by the respondents (Hair, Babin, Money, \& Samouel, 2005). According to Martins and Theóphilo (2007), the survey is suitable for cases in which questions about the distribution of a variable or the relationship between characteristics of individuals or groups need to be answered, and it is therefore suitable for the purposes of this research.

Due to convenience, the sample selection criterion is non-probabilistic. To ensure no duplicity, responses were filtered using IP addresses. Data collection occurred in the first half of 2014 and obtained 379 responses, of which 297 were suitable for the purposes of this research, representing $78.3 \%$. Access to the electronic questionnaire (e-survey) was sent through email and business social media (LinkedIn) using the researchers' contact network and post-graduation mailings. The questionnaire also went through a pre-test with nine respondents.

For data processing and analysis, Microsoft Excel tools (charts, graphs) were used, seeking to analyze the frequency and ranking of responses as well as to show possible associations between the variables studied. Later, the 20.0.0 version of the statistical package IBM SPSS (Statistical Package for the Social Sciences) was used to see, through the chi-square test, if there are statistical differences between the groups (Hair et al., 2005). This type of analysis was chosen to see if the corporate brand is perceived differently depending on the place that the company operates: national only, Brazilian operating abroad, or multinational with subsidiary in Brazil. It is important to note that this test does not consider cause-effect relations, apart from associations between groups (Sampieri, Collado, \& Lucio, 2006). Thus, from the chi-square test, the hypotheses were set out (as seen below), and the test was applied separately for each of the twelve categories of reasons presented in Table 2:

HO: the importance of reason " $\mathrm{X}$ " is not associated with the place where the company operates
$\mathrm{H} 1$ : the importance of reason " $\mathrm{X}$ " is associated with the place where the company operates

In addition, this study sought to understand if there are differences in the definitions of the corporate brand adopted (see Table 1) according to the organization's area of activity. Finally, it also sought to deepen the relations between corporate brand and international business by identifying the similarities and differences in the hierarchy of reasons that lead organizations to adopt a corporate brand strategy.

\section{Analysis and discussion of results}

In total, there were 297 valid questionnaires from management-level professionals (directors, managers, supervisors, and coordinators), and most of the respondents are male (54.7\%). There is a prevalence of people between 30 and 49 years old (72.9\%), especially in the range between 40 and 44 years old $(21 \%)$, indicating the senior level of the respondents. Hierarchical levels include managers and directors, which together account for $81.7 \%$. Regarding the area within the company, respondents mostly belong to the marketing, human resources, trade, and corporate and administrative communication areas (from $15.8 \%$ to $10.1 \%$ of respondents). The others (32.7\%) are made up of other areas.

In relation to company size, $49.5 \%$ declared being large, followed by $29.4 \%$ for medium-sized, and the rest were small. In order to let respondents show their perception of the company size an open-ended question was used. Regarding the segment of activity, more than half of the companies (54.9\%) operate in the service sector. Industry is the second largest company segment (33.6\%).

Finally, the variable related to the area of company operation is presented, which, among those characterizing the company, is important in answering the research question. In total, $41.8 \%$ of respondents said they work for companies that operate only in Brazil. Close to this percentage, 39.4\% said they worked for multinationals with subsidiaries in Brazil. And a smaller part, 18.9\%, stated that they work for Brazilian companies that have some operations abroad.

\subsection{Concept of corporate branding}

The definitions proposed for identifying the predominant aspects indicate differences in focus 
and approach to corporate branding, according to the Brazilian professionals' perception. Figure 1, which comprises the analysis of the sample in an aggregated fashion, shows the predominance of a view of the brand as a mechanism of expression of key company values and culture $-35.8 \%$ in total - followed by the approach focused on image and reputation, chosen by $31.1 \%$.

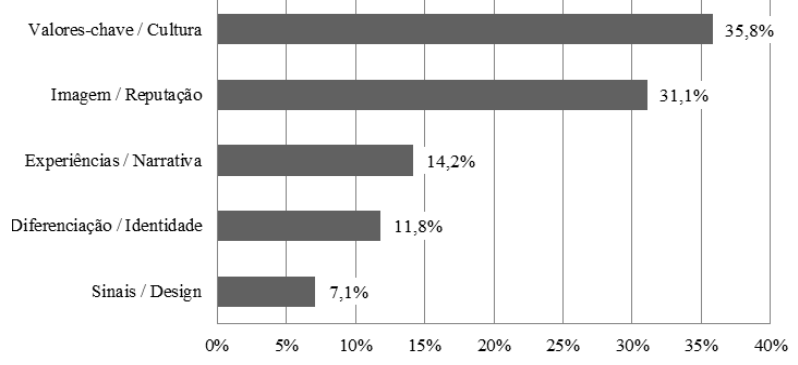

Fig. 1

Concept of corporate brand management Source: authors

The approach based on values and culture is in accordance with the identification of corporate branding as a critical capability, mechanisms of identity construction, and employee engagement, which are key factors in international business (Einwiller \& Will, 2002; Ghauri et al., 2011). Therefore, in the first instance, the brand can communicate and position the key value of the organization and the brand (Urde, 2003, 2009). This affects the results of the positive perception and credibility generated in stakeholders' minds (Keller \& Machado, 2006), a school guided by image. The more traditional school, focused on design and symbols, was mentioned only by $7.1 \%$ of respondents, which indicates an advance of the view of corporate branding based on meaning, which is far beyond visual identity.

Since this study focuses on the differences according to the place where companies operate (1) national with domestic operations, (2) national with operations abroad, (3) multinational with operations in Brazil - association tests were carried out for the groups using the chi-square test. No significant association between the five concepts was presented.

As the chi-square test indicated no significant association, this study sought to analyze only the frequency of perception of the concept of corporate branding by the professionals surveyed, who belong to the three subsamples. By analyzing only the frequency of responses, it is possible to observe differences of the two main approaches (key values/culture vs. image/reputation). Figure 2 shows that, in the group of companies with only national operations $(n=124)$, the corporate branding approach related to image and reputation is predominant. In the other two groups, national with operations abroad $(n=56)$ and foreign multinational ( $n=117$ ), the approach most mentioned by respondents is corporate branding as symbols associated with key values and culture.

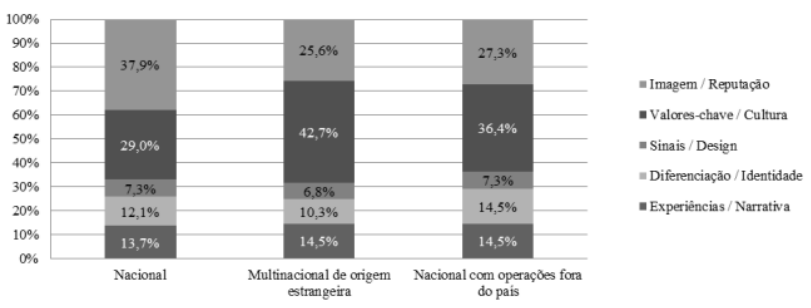

Fig. 2

Corporate brand management concept by place of operation Source: authors

Thus, analysis of the responses corroborates the perceived relevance of corporate branding as a useful tool for the challenges of building company culture with multinational operations. The mechanism of expression and strengthening of the key values may support the unique characteristics of each organization, as pointed to in previous studies (Einwiller \& Will, 2002), and the view of corporate branding as a critical internal capability (Ghauri et al., 2011), reinforcing its strategic role in the process of internationalization and providing the opportunity for future studies that better explore this association and its inclusion in marketing and global brand strategy.

\subsection{Reasons to adopt corporate branding}

From the results obtained, it was possible to list the main reasons that lead to the perception of importance in relation to the adoption of corporate branding. The study of frequencies was used for the analysis and interpretation of data, starting from the percentage of marked answers. To this end, they were put into the following groups: agreement ("strongly agree" and "partially agree"); disagreement ("strongly disagree" and "partially disagree"); and indifferent ("neither agree nor disagree"). The results obtained for the entire sample $(n=297)$ are shown as percentages in Table 3. The next analysis focuses on the five main reasons and 
compares the three groups of companies according to their geographic area.

The first reason is to strengthen commercial relationships with other businesses (B2B). For $86 \%$ of by $85 \%$. It is worth noting that the first three reasons have similar percentages, with the frequency of responses being very close in the agreement category.

Tab 3

Ranking of categories of reasons to adopt corporate branding ( $n=297$ )

\begin{tabular}{clccc}
\hline \multicolumn{1}{c}{ Reason } & Disagreement & Indifference & Agreement \\
\hline 1 & Commercial relations (B2B) & $3.5 \%$ & $10.4 \%$ & $86.0 \%$ \\
2 & Multinational operations and holdings & $3.9 \%$ & $10.9 \%$ & $85.2 \%$ \\
3 & Organizational identity & $5.9 \%$ & $9.1 \%$ & $85.0 \%$ \\
4 & War for talent (employer branding) & $7.7 \%$ & $11.4 \%$ & $80.8 \%$ \\
5 & Consumer attraction (B2C) & $8.6 \%$ & $12.5 \%$ & $79.0 \%$ \\
6 & Increase value in the capital market & $7.5 \%$ & $13.7 \%$ & $78.8 \%$ \\
7 & Synergy between brands (product and corporate) & $9.4 \%$ & $12.3 \%$ & $78.2 \%$ \\
8 & Strategic repositioning and change management & $8.9 \%$ & $16.0 \%$ & $75.1 \%$ \\
9 & Single face with stakeholders & $12.5 \%$ & $17.5 \%$ & $70.0 \%$ \\
10 & Image and reputation & $16.3 \%$ & $16.7 \%$ & $67.0 \%$ \\
11 & Social responsibility and sustainability (SRS) & $16.5 \%$ & $22.1 \%$ & $61.4 \%$ \\
12 & Demand for transparency & $26.8 \%$ & $30.1 \%$ & $43.1 \%$ \\
\hline
\end{tabular}

Source: authors

the respondents, corporate branding works to generate and leverage business with customers or sellers. Although it cannot be analyzed in isolation, this predominance reinforces the expansion of focus of corporate marketing in relationships with different stakeholders as well as the general view of the company (Balmer \& Gray, 2003; Balmer \& Greyser, 2006; Fetscherin \& Usunier, 2012; Ghauri et al., 2011).

For the second reason, the importance of corporate branding in the context of multinational operations and holdings was mentioned by $85.2 \%$ of the sample, since it allows the company to position itself equally in different countries that it operates in. The third reason relates to association with the company's own organizational identity, since corporate branding allows for the communication of company values and culture and creates a sense of belonging, which was mentioned by $85 \%$. It is worth noting that the first three reasons have similar percentages, with the frequency of responses being very close in the agreement category. For the second reason, the importance of corporate branding in the context of multinational operations and holdings was mentioned by $85.2 \%$ of the sample, since it allows the company to position itself equally in different countries that it operates in. The third reason relates to association with the company's own organizational identity, since corporate branding allows for the communication of company values and culture and creates a sense of belonging, which was mentioned
For the second reason, the importance of corporate branding in the context of multinational operations and holdings was mentioned by $85.2 \%$ of the sample, since it allows the company to position itself equally in different countries that it operates in. The third reason relates to association with the company's own organizational identity, since corporate branding allows for the communication of company values and culture and creates a sense of belonging, which was mentioned by $85 \%$. It is worth noting that the first three reasons have similar percentages, with the frequency of responses being very close in the agreement category.

Furthermore, $80.8 \%$ of respondents agree that a strong corporate brand favors the achievement and maintenance of the best professionals (Einwiller \& Will, 2002). When evaluating the items that appear in second, third, and fourth position, the argument proposed by Ghauri et al. (2011) is even more expressive. This is because it combines the challenge mentioned by the authors to attract, align, and engage employees in different locations, with the recognition of the potential of the corporate brand to express company values, which can become the differentiating element for employees and other stakeholders as they make the essence of the organization tangible.

Later analyses sought to identify similarities and differences depending on the place where the companies operate. When comparing the three 
groups according to location, as Table 4 shows, some patterns are repeated, although there are variations in the order they are presented in. There are three reasons in the first positions: those related to $\mathrm{B} 2 \mathrm{~B}$ commerce, organizational identity, and multinational operations and holdings. This latter reason appears in first place for the group of multinational companies with subsidiaries in Brazil, with the highest percentage of agreement among the groups (89.3\%). Interestingly, this reason appears within the first reasons for the adoption of corporate branding for Brazilian companies that only operate in Brazil.
Although it is not among the first topics, it is worth directing attention to the variation attributed to corporate branding in capital markets. For Brazilian companies with national and international operations this topic is more relevant - fifth place - when compared to foreign multinationals - seventh place. This difference is probably related to how far from the theme this latter category is, since they tend to have a closed nature in Brazil and are traded in stock exchanges abroad. For Brazilian companies, as they are usually traded in Brazil, the requirements of the financial market are more present.

Tab 2

Comparison of reasons for different groups

\begin{tabular}{|c|c|c|c|c|}
\hline & $\begin{array}{l}\text { Entire sample } \\
\quad(\mathrm{n}=297)\end{array}$ & $\begin{array}{c}\text { Companies operating } \\
\text { only nationally }(n=124)\end{array}$ & $\begin{array}{c}\text { Brazilian companies } \\
\text { operating abroad }(n=56)\end{array}$ & $\begin{array}{l}\text { Multinational companies with } \\
\text { subsidiaries in Brazil }(n=117)\end{array}$ \\
\hline $1^{\text {st }}$ & Commercial relations (B2B) & Commercial relations (B2B) & Organizational identity & $\begin{array}{l}\text { Multinational operations and } \\
\text { holdings }\end{array}$ \\
\hline $2^{\text {nd }}$ & $\begin{array}{l}\text { Multinational operations and } \\
\text { holdings }\end{array}$ & Organizational identity & War for talent & Commercial relations (B2B) \\
\hline $3^{\text {rd }}$ & Organizational identity & $\begin{array}{l}\text { Multinational operations and } \\
\text { holdings }\end{array}$ & Commercial relations (B2B) & Organizational identity \\
\hline $4^{\text {th }}$ & War for talent & Consumer attraction (B2C) & $\begin{array}{l}\text { Multinational operations and } \\
\text { holdings }\end{array}$ & War for talent \\
\hline $5^{\text {th }}$ & Consumer attraction (B2C) & Increase value in capital market & Increase value in capital market & Synergy between brands \\
\hline $6^{\text {th }}$ & Increase value in capital market & Synergy between brands & Consumer attraction (B2C) & Consumer attraction (B2C) \\
\hline $7^{\text {th }}$ & Synergy between brands & War for talent & Synergy between brands & Increase value in capital market \\
\hline $8^{\text {th }}$ & $\begin{array}{l}\text { Strategic repositioning and } \\
\text { change }\end{array}$ & $\begin{array}{l}\text { Strategic repositioning and } \\
\text { change }\end{array}$ & $\begin{array}{l}\text { Strategic repositioning and } \\
\text { change }\end{array}$ & $\begin{array}{l}\text { Strategic repositioning and } \\
\text { change }\end{array}$ \\
\hline $9^{\text {th }}$ & Single face with stakeholders & Image and reputation & Single face with stakeholders & Single face with stakeholders \\
\hline $10^{\text {th }}$ & Image and reputation & Single face with stakeholders & Image and reputation & Image and reputation \\
\hline $11^{\text {th }}$ & $\begin{array}{l}\text { Social responsibility and } \\
\text { sustainability }\end{array}$ & $\begin{array}{l}\text { Social responsibility and } \\
\text { sustainability }\end{array}$ & $\begin{array}{l}\text { Social responsibility and } \\
\text { sustainability }\end{array}$ & $\begin{array}{l}\text { Social responsibility and } \\
\text { sustainability }\end{array}$ \\
\hline $12^{\text {th }}$ & Demand for transparency & Demand for transparency & Demand for transparency & Demand for transparency \\
\hline
\end{tabular}

Source: authors

It is also interesting to note the change of perspective depending on whether the company headquarters is Brazilian or foreign. For respondents who work at companies with Brazilian headquarters, corporate branding gains greater importance due to the capability to communicate the identity locally and internationally. On the other hand, in foreign companies, the perspective of alignment in various locations stands out, with Brazil being one of them. The reason "war for talent" is also highlighted. In the group of Brazilian companies with only domestic operations it appears only in seventh place, while in the other groups it is one of the main reasons. It is interesting to note that, in these organizations, employer branding appears above consumer attraction and synergy with product brands, which indicates that corporate branding is a focus in stakeholder relationship strategies (Douglas \& Craig, 2013; Ghauri et al., 2011; Xie \& Boggs, 2006).
However, for the three groups the reasons "social responsibility and sustainability" and "demand for transparency" are placed at the bottom of the ranking, which is against many arguments that consider access to information and technological changes as one of the main reasons for corporate branding, along with the requirement of corporate citizenship. Therefore, it was noted that the concept of corporate branding is predominantly seen as the potential capability to project identity. External perception bias appears as one of the last reasons image and reputation (67\% agreement), way of communicating social responsibility (61.4\%), and demand for transparency (43.1\%). Interestingly, several studies address sustainability and social responsibility as reputation mechanisms, including in international business (Gupta \& Kumar, 2013). The result becomes coherent if interpreted in the light of corporate identity, since these aspects are only valid in positioning if they are part of the organization's 
values, channeled by the ability to communicate its culture and essence.

\subsection{Scope of operation versus views on corporate branding}

Finally, this study sought to confirm if there is an association between i.) the scope of operation of the surveyed companies and ii.) the reasons for adopting corporate branding, and if this is statistically significant - according to the hypothesis - using the chi-square test.

HO: the importance of reason " $X$ " is not associated with the place where the company operates

H1: the importance of reason " $X$ " is associated with the place where the company operates

At first, the analyses conducted in SPSS indicated that the essential premise of the technique, which requires an expected frequency equal or superior to five observations for each category, was not met. In such cases, the procedure is to recombine two adjacent categories. By recombining Brazilian companies (those with domestic operations and those operating abroad) in a group or companies with international operations (Brazilian companies that operate abroad and multinationals with operations in Brazil), the premise was fulfilled. Finally, statistical analyses showed that the importance attributed to each of the twelve categories of reasons is not associated with the scope of the companies' operations.

The results indicate that whether the company is internationalized or not does not significantly interfere in the hierarchy of reasons perceived as important to the adoption of corporate branding. However, they allowed the reasons and benefits to adopt corporate branding strategy to be explored, especially in the construction of company identity and creation of meaning with various stakeholders, especially employees. As this study is descriptive and exploratory and its objective is to offer a preliminary view on corporate branding in an international business context, it fulfilled its purpose by providing a basis for future research and broadening perspectives on product brands and the architecture of brand positioning.

\section{Final considerations}

In an increasingly complex context for organizations and their internationalization, corporate branding is an important element in strategy as a critical internal capability and source of competitive advantage. The empirical study carried out in this study aimed to verify the understanding of the importance of adopting corporate branding according to companies' scope of operation - that is, national or multinational companies.

This first survey reinforces the importance of the institutional and corporate level of brand architecture through corporate brand management (Balmer \& Gray, 2003; Xie \& Boggs, 2006), contributing to academic reflection on the adoption of corporate brands as a critical capability and source of competitive advantage. The complexity and criticality of attracting and engaging the workforce in international business (Ghauri et al., 2011) leads to the strengthening of the corporate branding's internal approach and focuses on corporate identity (Fetscherin \& Usunier, 2012). The predominance of the conceptual view of corporate brands' organizational identity as a mechanism for culture building and the expression of key values in international operations corroborates the complexity of building a common and unique positioning to integrate and manage operations in multinationals.

Being exploratory, this study advanced as far as the collected data allowed. By using a comprehensive list of reasons for the adoption of corporate branding, it was expected that the results would have minor alterations when identifying subtleties in perceptions, resulting in limitations in data processing. The sample does not allow generalizations, but provides an initial overview of corporate branding in international operations. This corroborates Ghauri et al.'s (2011) proposition by indicating that there is potentially a strong relationship between corporate branding strategy and international operations, paving the way for future studies and revealing practical implications for brand management in companies and the global market. As for future studies, this study demonstrates opportunities to deepen studies on global corporate branding and brand architecture in order to include discussion on corporate brands as well as correlations with internationalization strategies and the analyzed factors, which could include performing correlational and explanatory 
studies. It may also be interesting to verify the type and/or intensity of companies' internationalization according to the strength of their corporate brands.

Considering the challenges of international business both in local administration and in global integration, corporate brand construction and management can become a relevant strategic tool, since it allows for the communication in a consistent and distinctive way of unique company characteristics as well as the shaping of internationalization strategies and relationships with strategic stakeholders.

\section{References}

- Aaker, D. a. (2004). Leveraging the Corporate Brand. California Management Review, 46(3), 6-18. http://doi.org/10.2307/41166218

- Argenti, P. A. (2005). Comunicação Empresarial: A Construção da Identidade, Imagem e Reputação. (Tradução Adriana Rieche, Ed.) (1a.). Rio de Janeiro: Elsevier Ltd.

- Balmer, J. M. T. (2009). Corporate marketing: apocalypse, advent and epiphany. Management Decision, 47(4), 544572. http://doi.org/10.1108/00251740910959413

- Balmer, J. M. T. (2010). Explicating corporate brands and their management: Reflections and directions from 1995. Journal of Brand Management, 18(3), 180-196. http://doi.org/10.1057/bm.2010.46

- Balmer, J. M. T. (2012). Strategic corporate brand alignment: Perspectives from identity based views of corporate brands. European Journal of Marketing, 46(7/8), 1064-1092. http://doi.org/10.1108/03090561211230205

- Balmer, J. M. T., \& Gray, E. R. (2003). Corporate brands: what are they? What of them? European Journal of Marketing, $37(7 / 8)$, 972-997. http://doi.org/10.1108/03090560310477627

- Balmer, J. M. T., \& Greyser, S. (2006). Corporate marketing: Integrating corporate identity, corporate branding, corporate communications, corporate image and corporate reputation. European Journal of Marketing, 40(7/8), 730741. http://doi.org/10.1108/03090560610669964

- Cavusgil, S. T., Deligonul, S., \& Yaprak, A. (2005). International Marketing as a Field of Study: A Critical Assessment of Earlier Development and a Look Forward. Journal of International Marketing, 13(4), 1-27. http://doi.org/10.1509/jimk.2005.13.4.1

- Cavusgil, S. T., Knight, G., \& Riesenberger, J. R. (2010). Negócios Internacionais: estratégia, gestão e novas realidades. São Paulo: Pearson Prentice Hall.

- Chabowski, B. R., Samiee, S., \& Hult, G. T. M. (2013). A bibliometric analysis of the global branding literature and a research agenda. Journal of International Business Studies, 44(6), 622-634. http://doi.org/10.1057/jibs.2013.20
- Cheney, G., Christensen, L. T., Zorn, T. E., \& Ganesh, S. (2004). Organizational Communication in an Age of Globalization. Illinois: Waveland Press.

- Corte, V. Della, \& Mangia, G. (2011). Strategic Employer Branding: Brand and Image Management as a Tool of Attractiveness for Talented Capital. China-USA Business Review, 10(12), 1231-1252.

- Đorđević, B. (2008). Corporate strategic branding: How country and corporate brands come together. Ekonomski Anali, 53, 59-89. http://doi.org/10.2298/EKA08177059D

- Douglas, S., \& Craig, C. (2013). Dynamics of international brand architecture: Overview and directions for future research. DYNAMICS, 21(September), 916-932.

- Douglas, S. P., Craig, C. S., \& Nijssen, E. J. (2001). Exeuctive Insights: Integrating Branding Strategy Across Markets: Building International Brand Architecture. Journal of International Marketing, 9(2), 97-114. http://doi.org/10.1509/jimk.9.2.97.19882

- Einwiller, S., \& Will, M. (2002). Towards an integrated approach to corporate branding - an empirical study. Corporate Communications: An International Journal, 7(2), 100-109. http://doi.org/10.1108/13563280210426160

- Fetscherin, M., \& Usunier, J. (2012). Corporate branding: an interdisciplinary literature review. European Journal of Marketing, 46(5), 733-753. http://doi.org/10.1108/03090561211212494

- Fleury, M. T. L., \& Fleury, A. (2012). Multinacionais Brasileiras: Competências para a Internacionalização. Rio de Janeiro: Editora FGV.

- Ghauri, P. N., Elg, U., Tarnovskaya, V., \& Fatima, W. (2011). Developing a market driving strategy for foreign markets: Internal capabilities and external activities. Schmalenbach Business Review, 11(3), 1-23.

- Ghauri, P. N., \& Santangelo, G. D. (2012). Multinationals and the Changing Rules of Competition. Management International Review, 52(2), 145-154. http://doi.org/10.1007/s11575-012-0130-7

- Glynn, M. S., Motion, J., \& Brodie, R. J. (2007). Sources of brand benefits in manufacturer-reseller B2B relationships. Journal of Business \& Industrial Marketing, 22(6), 400-409. http://doi.org/10.1108/08858620710780163

- Gupta, S., \& Kumar, V. (2013). Sustainability as corporate culture of a brand for superior performance. Journal of World Business, 48(3), 311-320. http://doi.org/10.1016/j.jwb.2012.07.015

- Guzmán, F., \& Paswan, A. (2009). Cultural brands from emerging markets: brand image across host and home countries. Journal of International Marketing, 17(3), 71-86. Retrieved from http://journals.ama.org/doi/abs/10.1509/jimk.17.3.71

- Hair, J. J. F., Babin, B., Money, A. H., \& Samouel, P. (2005). Fundamentos de métodos de pesquisa em administração. (Tradução: Lene Belon Ribeiro, Ed.). Porto Alegre: Bookman.

- Harris, F., \& Chernatony, L. De. (2001). Corporate branding and corporate brand performance. European Journal of 
Marketing, 35(3/4), 441-456. http://doi.org/10.1108/03090560110382101

- Hatch, M. J., \& Schultz, M. (2003). Bringing the corporation into corporate branding. European Journal of Marketing, $37(7 / 8)$,

1041-1064. http://doi.org/10.1108/03090560310477654

- Hatch, M. J., \& Schultz, M. (2008). Taken Brand Initiative: how companies can align strategy, culture, and identity through corporate branding (1st ed.). San Francisco: JosseyBass.

- Hatch, M. J., \& Schultz, M. (2009). Of Bricks and Brands: Organizational Dynamics, 38(2), 117-130. http://doi.org/10.1016/j.orgdyn.2009.02.008

- Kapferer, J. (2005). The post-global brand. The Journal of Brand Management, 12(5), 319-324.

- Katobe, M. (2001). Contemporary Research Trends in International Marketing: The 1990s. In A. M. Rugman \& T. I. Brewer (Eds.), The Oxford Handbook of International Business. Oxford: Oxford University Press Inc.

- Kay, M. J. (2006). Strong brands and corporate brands. European Journal of Marketing, 40(7/8), 742-760. http://doi.org/10.1108/03090560610669973

- Keller, K. L., \& Machado, M. (2006). Gestão Estratégica de Marcas. São Paulo -SP: Pearson Prentice Hall.

- King, S. (1991). Brand building in the 1990s. Journal of Consumer Marketing, 8(4), 43-52. http://doi.org/10.1108/07363769110035144

- Knox, S., \& Bickerton, D. (2003). The six conventions of corporate branding. European Journal of Marketing, 37(7/8), 998-1016. http://doi.org/10.1108/03090560310477636

- Kotler, P., \& Pfoertsch, W. (2007). Being known or being one of many: the need for brand management for business-tobusiness (B2B) companies. Journal of Business \& Industrial Marketing, 22(6), 357-362. http://doi.org/10.1108/08858620710780118

- Lakatos, E. M., \& Marconi, M. de A. (2003). Metodologia Científica (5th ed.). São Paulo -SP: Atlas.

- Leek, S., \& Christodoulides, G. (2011). A literature review and future agenda for B2B branding: Challenges of branding in a B2B context. Industrial Marketing Management, 40(6), 830837. http://doi.org/10.1016/j.indmarman.2011.06.006

- Lim, K., \& O'Cass, A. (2001). Consumer brand classifications: an assessment of culture-of-origin versus country-of-origin. Journal of Product \& Brand Management, 10(2), 120-136.

- Martins, G. de A., \& Theóphilo, C. R. (2007). Metodologia da Investigação Científica para Ciências Sociais Aplicadas. São Paulo -SP: Atlas.

- Muzellec, L., \& Lambkin, M. C. (2009). Corporate branding and brand architecture: a conceptual framework. Marketing Theory, 9(1), 39-54. http://doi.org/10.1177/1470593108100060
- Olins, W. (1989). Corporate identity making business strategy visible throught design. Boston: Harvard Business School Press.

- Pérez, A., \& del Bosque, I. R. (2014). Organizational and Corporate Identity Revisited: Toward a Comprehensive Understanding of Identity in Business. Corporate Reputation Review, 17(1), 3-27. http://doi.org/10.1057/crr.2013.22

- Pharr, J. (2005). Synthesizing country-of-origin research from the last decade: is the concept still salient in an era of global brands? Journal of Marketing Theory and Practice, 13(4), 34-. Retrieved from http://www.jstor.org/stable/40470235

- Rodrigues, J., Miyahira, N. N., Mariano, M., \& Marinho, B. D. L. (2014). Por que Marcas Corporativas? A percepção de executivos brasileiros sobre os motivos para adotar corporate branding. In X Congresso de Administração da ESPM. São Paulo: ESPM.

- Sampieri, R. H., Collado, C. F., \& Lucio, P. B. (2006). Metodologia de Pesquisa (3rd ed.). São Paulo: McGraw-Hill.

- Sheikh, A., \& Lim, M. (2011). Engineering consultants' perceptions of corporate branding: A case study of an international engineering consultancy. Industrial Marketing Management, 40(7), 1123-1132. http://doi.org/10.1016/j.indmarman.2011.09.006

- Urde, M. (2003). Core value-based corporate brand building. European Journal of Marketing, 37(7/8), 1017-1040. http://doi.org/10.1108/03090560310477645

- Urde, M. (2009). Uncovering the corporate brand's core values. Management Decision, 47(4), 616-638. http://doi.org/10.1108/00251740910959459

- Urde, M. (2013). The corporate brand identity matrix. Journal of Brand Management, 20(9), 742-761. http://doi.org/10.1057/bm.2013.12

- van Riel, C. B. M., \& Balmer, J. M. T. (1997). Corporate identity: the concept, its measurement and management. European Journal of Marketing, 31(5/6), 340-355. http://doi.org/10.1108/eb060635

- van Riel, C. B. M., \& Fombrun, C. J. (2007). Essentials of Corporate Communication: Implementing Practices for Effective Reputation Management. New York - NY: Routledge.

- Vergara, S. C. (2009). Projetos e relatórios de pesquisa em administração (10th ed.). São Paulo: Atlas.

- Xie, H. Y., \& Boggs, D. J. (2006). Corporate branding versus product branding in emerging markets. Marketing Intelligence \& Planning, 24(4), 347-364. http://doi.org/10.1108/02634500610672099

- Zou, S., \& Cavusgil, S. (2002). The GMS: a broad conceptualization of global marketing strategy and its effect on firm performance. Journal of Marketing, 66(October), 40-56. Retrieved from http://journals.ama.org/doi/abs/10.1509/jmkg.66.4.40.185 19 


\section{About the authors}

- Juliana Rodrigues holds a master's degree in Business Administration from Universidade de São Paulo USP and a degree in Public Relations from Casper Líbero College.Email: jurodrigues@usp.br

- Bruno Mazzola holds a doctorate in Business Administration from Universidade de São Paulo - USP. He has a master's degree and undergraduate degree in Administration from the same institution. He teaches in undergraduate and postgraduate courses at FECAP, FIA, UNIP and Estácio. Email: bruno.mazzola@usp.br

- Mariana Bassi Sutter is Professor of Marketing at York University. PhD and master in business administration from Universidade de São Paulo - USP.Email: mbsutter@gmail.com

- Ney Nakazato Miyahira holds a doctorate and a master's degree in Business Administration from USP. Graduated in Administration by FGV and Law by USP.Email: neymiyahira@usp.br

- Maria Tereza Leme Fleury is a full professor at FGV EAESP in International Strategy. Email: mtereza.fleury@fgv.br 


\title{
A visão da marca corporativa em operações internacionais
}

\author{
Juliana Rodrigues ${ }^{\mathrm{A}}$, Bruno MazzolaA, Mariana Bassi Sutter ${ }^{\mathrm{B}}$, \\ Ney Nakazato Miyahira ${ }^{A}$ e Maria Tereza Leme Fleury ${ }^{C}$ \\ ${ }^{A}$ Universidade de São Paulo - USP, São Paulo, SP, Brasil \\ ${ }^{B}$ The University of York, York, England, United Kingdom \\ ${ }^{c}$ Fundação Getúlio Vargas, FGV EAESP, São Paulo, SP, Brasil
}

\section{DETALHES DO ARTIGO}

\section{Histórico do artigo:}

Recebido em 5 de março de 2016

Aceito em 14 de março de 2017

Disponível online em 30 April 2017

Sistema de Revisão "Double Blind Review"

Editor científico:

Ilan Avrichir

\section{Palavras-chaves:}

Corporate brand

Corporate branding

International marketing

Brand architecture

International business

\begin{abstract}
RESUMO
A estratégia de marcas corporativas vem ganhando cada vez mais relevância nos movimentos de internacionalização das empresas. No entanto, poucos estudos abordam diretamente a relação entre marca corporativa e internacionalização. O presente trabalho busca aproximar os temas, evidenciando a marca corporativa como capacidade crítica da organização na relação com diferentes stakeholders. Para tanto, foi realizada uma ampla revisão da literatura sobre corporate branding em negócios internacionais, bem como abordagens de marca corporativa. Foi conduzida uma pesquisa quantitativa exploratória, por meio de uma survey, com 297 profissionais de nível de gestão de empresas no Brasil, tendo como pergunta central verificar se o âmbito de operação da empresa, seja local ou multinacional, interfere na visão sobre marca corporativa. Os achados destacam a construção da identidade em multinacionais como um dos principais motivos para adotar marcas corporativas. No entanto, o âmbito de atuação da empresa não interfere, de maneira expressiva, na hierarquia de motivos percebidos como relevantes na adoção da marca corporativa. A predominância da definição da marca corporativa pela abordagem de expressão dos valores-chave entre respondentes pertencentes a multinacionais corrobora com sua identificação como ferramenta útil na construção de identidade em operações internacionais, evidenciando a relevância do tema para pesquisas futuras. (c) 2017
\end{abstract}

Internext | ESPM. All rights reserved.

To cite this article:

Rodrigues, J.; Mazzola, B.; Sutter, M. B.; Miyahira, N. K.; Fleury, M. T. L. (2017). The corporate branding approach in international operations. Internext - Revista Eletrônica de Negócios Internacionais, 12 (1), 1 15. DOI: 10.18568/1980-4865.1211-15

To access this article: http://dx.doi.org/10.18568/1980-4865.1211-15 